\title{
The influence of the pattern of moving rainstorms on overland flow
}

\author{
J.L.M.P. de Lima ${ }^{a, *}$, V.P. Singh ${ }^{b}$ \\ ${ }^{a}$ Department of Civil Engineering, Faculty of Science and Technology, IMAR_Institute of Marine Research, Coimbra Interdisciplinary Centre, \\ Campus 2, University of Coimbra, 3030-290 Coimbra, Portugal \\ ${ }^{\mathrm{b}}$ Department of Civil and Environmental Engineering, Louisiana State University, Baton Rouge, LA 70803-6405, USA \\ Received 29 October 2000; received in revised form 16 October 2001; accepted 8 December 2001
}

\begin{abstract}
This study emphasizes the importance of spatial rainfall intensity patterns of moving rainstorms on overland flow. A simple numerical model, based on the non-linear kinematic wave, was used for comparing the results for hypothetical storms moving up and down an impervious plane surface. Simulations were undertaken by varying the storm pattern, length, speed and direction. No account was made for time varying losses, such as infiltration, evaporation, etc. The results indicate significant differences in peak discharges and hydrograph shapes for moving storms of various patterns. The sensitivity of runoff to storm patterns decreases as storm speed increases.
\end{abstract}

(C) 2002 Elsevier Science Ltd. All rights reserved.

Keywords: Rainfall pattern; Kinematic wave; Overland flow; Storm movement

\section{Introduction}

The hydraulic characteristics of overland flow are strongly related to the characteristics and spatial variability of rainfall. The areal coverage of rainfall storms may vary with their type. Some rainfall storms concentrate in a small area while others spread over considerable large areas. Heavy rainfall in small areas is caused mainly by convective thunderstorms. Rainfall intensity has a large correlation with the vertical stability of the air and also has a close relation with orographic conditions [14]. Also, rainfall is frequently generated by moving storms. The problem of storm movement affecting flows (shape of the hydrograph and peak discharges) has been recognized for a long time (e.g., $[6,13,22,24])$. The influence of a moving storm on the hydraulics of underlying overland flow is dependent on its direction, speed, length and pattern. Wind also affects the mean drop size, drop incidence angle and drop

\footnotetext{
${ }^{*}$ Corresponding author. Tel.: +351-239-797-183; fax: +351-239-797179.

E-mail addresses: plima@dec.uc.pt (J.L.M.P. de Lima), cesing@ lsu.edu (V.P. Singh).
}

speed, which also can significantly affect the mechanics of overland flow (e.g., [7-10]).

Overland flow with rainfall as a source of lateral inflow can be treated as an unsteady, shallow, open channel flow problem which occurs in natural watersheds and also in urban drainage areas. Several theoretical studies have been published about Hortonian overland flow [4] generated by rainfall on slopes of various shapes (e.g., $[1,5,11,16-19,21,25,27])$. Some of these studies use the non-linear kinematic wave approach. Although overland flow could ideally be represented by the Saint-Venant equations, the kinematic solutions have been shown to yield very reliable results for most hydrologically significant cases [20]. Thus the kinematic wave modelling is gaining wide acceptance as a fast and accurate way to handle not only overland flow but also a wide range of water modelling problems [20]. Also, kinematic modelling can account for detailed spatially distributed dynamic representations of rainfall.

The objective of this study was to study the influence of storm pattern, with respect to storm motion, on the shape of the runoff hydrograph, time to peak and peak discharge. The storms moved up and down the plane at a range of speeds, simulating one single dry-wet-dry cycle as shown in Fig. 1. 


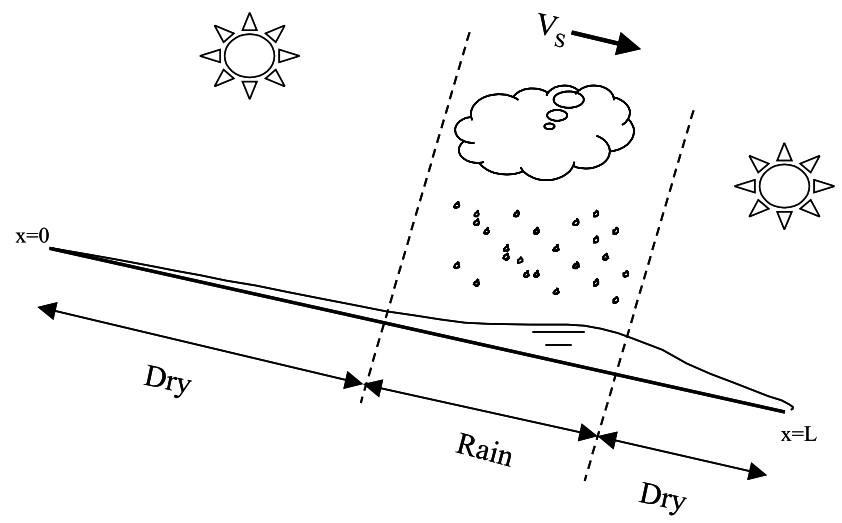

Fig. 1. Dry-wet-dry cycle on a plane due to a downstream moving rainstorm, where: $V_{\mathrm{S}}$ is the speed of the storm; $x$ is the distance from top of field along the flow direction; and $L$ is the total length measured along the slope.

\section{Methodology}

The kinematic wave theory was used to investigate the influence of storm movement on overland flow. The kinematic wave governing equation was solved numerically for moving storms on a one-dimensional runoff plane for the following situations: storm direction (downslope and upslope); storm speed ( $V_{\mathrm{s}}$ from 0.5 to 5 $\mathrm{m} / \mathrm{s}$ ); storm length (smaller, equal and longer than slope length); and storm pattern (i.e., four hypothetical rainfall intensity patterns that were entitled uniform, intermediate, advanced and delayed, and are presented in Fig. 3).

\subsection{Basic equations and numerical scheme}

Any appropriate mathematical formulation of overland flow makes use of the fundamental mass and momentum equations. The equation of continuity (representing the conservation of mass) for shallow water flow (one dimension) may be written as:

$\frac{\partial h}{\partial t}+\frac{\partial Q}{\partial x}=q(x, t)$

where $h$ is the overland flow water depth $(\mathrm{m}), t$ is the time (s), $x$ is the distance from the top of the field along the flow direction $(\mathrm{m}), Q$ is the discharge per unit width $\left(\mathrm{m}^{2} / \mathrm{s}\right)$, and $q(x, t)$ is the lateral inflow or rainfall excess rate $(\mathrm{m} / \mathrm{s})$. Thus, $q(x, t)$ can, in this formulation, be varied in both space and time.

For simplicity, the following is assumed: the flow is one-dimensional; the plane is impervious; hydrostatic pressure distribution is valid across the flow depth; the surface tension forces are negligible; the variation of the momentum coefficient $\beta$ along the $x$-direction is negligible; and the slope is small. By also assuming that the slope of the field $S_{\mathrm{o}}$ equals the friction slope $S_{\mathrm{f}}$ (kinematic wave assumption) and by using existing open- channel flow friction equations we can express the overland flow discharge at any point and time as a function of the water depth only as follows (Bakmeteff relation):

$Q=\alpha h^{n}$

where $\alpha$ is an empirical coefficient basically linked to the slope and the roughness, and $n$ is an exponent which is also empirical.

Consequently, the overland flow discharge at the end of the plane is:

$Q_{L}=\alpha h_{L}^{n}$

where $L$ is the total length measured along the slope (m).

For turbulent flow, if we use Manning's formula $\left(Q=k_{\mathrm{M}} h^{5 / 3} S_{\mathrm{f}}^{1 / 2}\right)$, we then get:

$\alpha=k_{\mathrm{M}} S_{\mathrm{f}}^{1 / 2}$

$n=5 / 3$

where $k_{\mathrm{M}}$ is the Manning's roughness coefficient $\left(\mathrm{m}^{1 / 3} / \mathrm{s}\right)$, and $S_{\mathrm{f}}$ the friction slope.

Substituting Eq. (2) in Eq. (1), the kinematic-wave equation can be written as:

$\frac{\partial h}{\partial t}+n \alpha h^{n-1} \frac{\partial h}{\partial x}=q(x, t)$

Eq. (6) is the governing kinematic wave equation which is solved using the Lax-Wendroff scheme. This is one of the most popular numerical methods for solution of the kinematic wave equations. The scheme involves a triangular approximation and is a second-order single-step numerical scheme. It can be expressed in finite-difference form as (a complete derivation of this equation is given in [20]):

$$
\begin{aligned}
h_{j}^{i+1}= & h_{j}^{i}+\Delta t\left(q_{j}^{i}-n \alpha \frac{h_{j+1}^{n^{n-1}}+h_{j-1}^{i^{n-1}}}{2} \frac{h_{j+1}^{i}-h_{j-1}^{i}}{2 \Delta x}\right) \\
& +\frac{(\Delta t)^{2}}{2} \frac{q_{j}^{i+1}-q_{j}^{i}}{\Delta t} \\
& -\frac{(\Delta t)^{2}}{2} \alpha n\left[\frac { h _ { j + 1 } ^ { i ^ { n - 1 } } + h _ { j } ^ { i ^ { n - 1 } } } { 2 } \left(\frac{q_{j+1}^{i}+q_{j}^{i}}{2}\right.\right. \\
& \left.-n \alpha \frac{h_{j+1}^{i^{n-1}}+h_{j}^{i^{n-1}}}{2} \frac{h_{j+1}^{i}-h_{j}^{i}}{\Delta x}\right) \\
& \left.-\frac{h_{j}^{i^{n-1}}+h_{j-1}^{i^{n-1}}\left(\frac{q_{j}^{i}+q_{j-1}^{i}}{2}\right.}{2}\left(\frac{h_{j}^{i^{n-1}}+h_{j-1}^{i^{n-1}}}{2} \frac{h_{j}^{i}-h_{j-1}^{i}}{\Delta x}\right)\right] / \Delta x
\end{aligned}
$$

where position $x$ is denoted by $j$ and time $t$ is denoted by $i$.

For $x=L$ (the downstream boundary), a first-order scheme is employed [20]: 
$h_{j}^{i+1}=h_{j}^{i}+\Delta t\left(q_{j}^{i}-n \alpha \frac{h_{j}^{i^{n-1}}+h_{j-1}^{i^{n-1}}}{2} \frac{h_{j}^{i}-h_{j-1}^{i}}{\Delta x}\right)$

The values of $\Delta x$ and $\Delta t$ were fixed during the simulation. Thus the grid system is uniform in space and time. Sufficient simulation time was allowed for the establishment of no-flow conditions after the storm.

To guarantee the stability of Eqs. (7) and (8) the ratio $\Delta t / \Delta x$ must satisfy the Courant condition for linear numerical stability [2,23]:

$\frac{\Delta t}{\Delta x} \leqslant \frac{1}{n \alpha h^{n-1}}$

\subsection{Catchment geometry and physical characteristics}

In this study we investigate the influence of a certain rainfall intensity pattern, fixed in time (for simplicity) and with a certain spatial extent, moving across a catchment. Ideally, this investigation of the effect of storm patterns should be undertaken for a range of physical properties of the catchment. However, we will concentrate on the rainfall intensity patterns and simplify the geometry and characteristics of the surface. Since different rainfall distribution patterns were assigned to move along the catchment, it was decided to use the simplest possible geometry for the idealized catchment consisting of an impervious plane surface (e.g., impermeable area in an urban environment; impervious hillslope plane). The plane (rectangular shape) was $100 \mathrm{~m}$ in length and $1 \mathrm{~m}$ in width (unit width) with a gradient of $10 \%$. The plane was discretised in, at least, 20 segments. The roughness characteristics of the plane were assumed to be constant with a Manning's value of $k_{\mathrm{M}}=10 \mathrm{~m}^{1 / 3} / \mathrm{s}$, even during the recession of the hydrograph.

\subsection{Rainfall patterns}

The temporal pattern of a storm is determined by the arrangement of the rainfall intensity histogram. Storm patterns are important because they are one of the important factors determining the shape of the runoff hydrograph. Lateral inflow can be represented as a histogram in time, as presented in Fig. 2.

To evaluate the hydrologic response of storm movement, a fixed lateral inflow pattern with a certain spatial extent was considered moving in space, which induced a rainfall temporal pattern, in each $\Delta x$ of the plane, depending on the speed of the storm. Arbitrary selected storm patterns of rainfall intensity used in this study are shown in Fig. 3.

For a given storm a constant spatial intensity pattern was maintained for the entire duration of the simulation (time required for the storm to cross the plane). Since one-dimensional flow was considered, the spatial rainfall
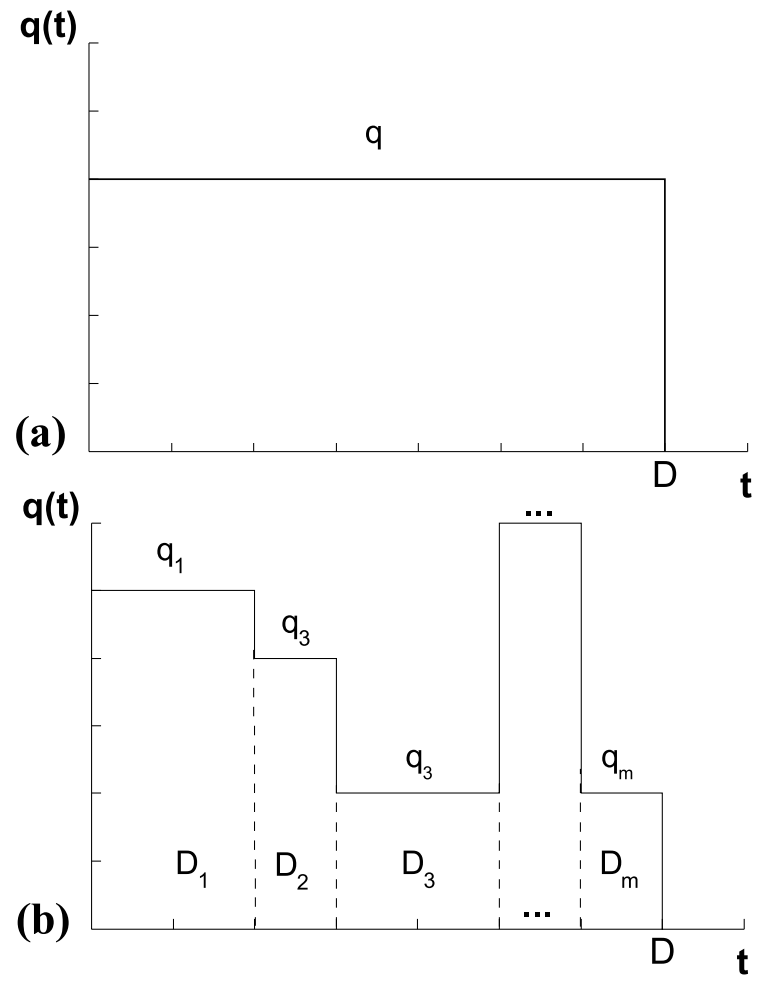

Fig. 2. (a) Histogram composed of one pulse, where $D$ is the duration of the storm; and (b) Histogram composed of pulses. Each pulse has a different value of lateral inflow $q$ and duration $D_{i}\left(q_{i} \neq q_{i+1}, D_{i} \neq D_{i+1}\right.$, $i=1,2,3, \ldots, m)[20]$.

intensity patterns did not vary in the direction perpendicular to the flow direction, as represented in Fig. 4, for an intermediate pattern.

Let us consider the motion of a rectangular block storm (uniform pattern-Fig. 3) over an impervious plane surface, as represented in Fig. 5.

On the plane catchment surface (Fig. 5), the rainfall intensity or lateral inflow $q$, in time, is represented in Fig. 6.

The total time, the rainfall is felt on the surface (duration of the storm) from the instant the rainfall enters (at $x=0$ ) until it leaves (at $x=L$ ) the surface, is:

$D=\frac{\left(L+L_{\mathrm{S}}\right)}{V_{\mathrm{S}}}$

where $D$ is the duration of the storm (s), $L$ is the length of plane (m), $L_{\mathrm{S}}$ is the length of storm (m), and $V_{\mathrm{S}}$ is the speed of the storm $(\mathrm{m} / \mathrm{s})$.

The total rainfall dropped on the surface by the storm moving across the plane is:

$h=q \frac{L_{\mathrm{S}}}{V_{\mathrm{S}}}$

where $h$ is the total rainfall (m).

For a complex storm pattern, it is possible to decompose the storm in several rain blocks. The total rainfall is then given by: 


\section{Direction of storm movement}
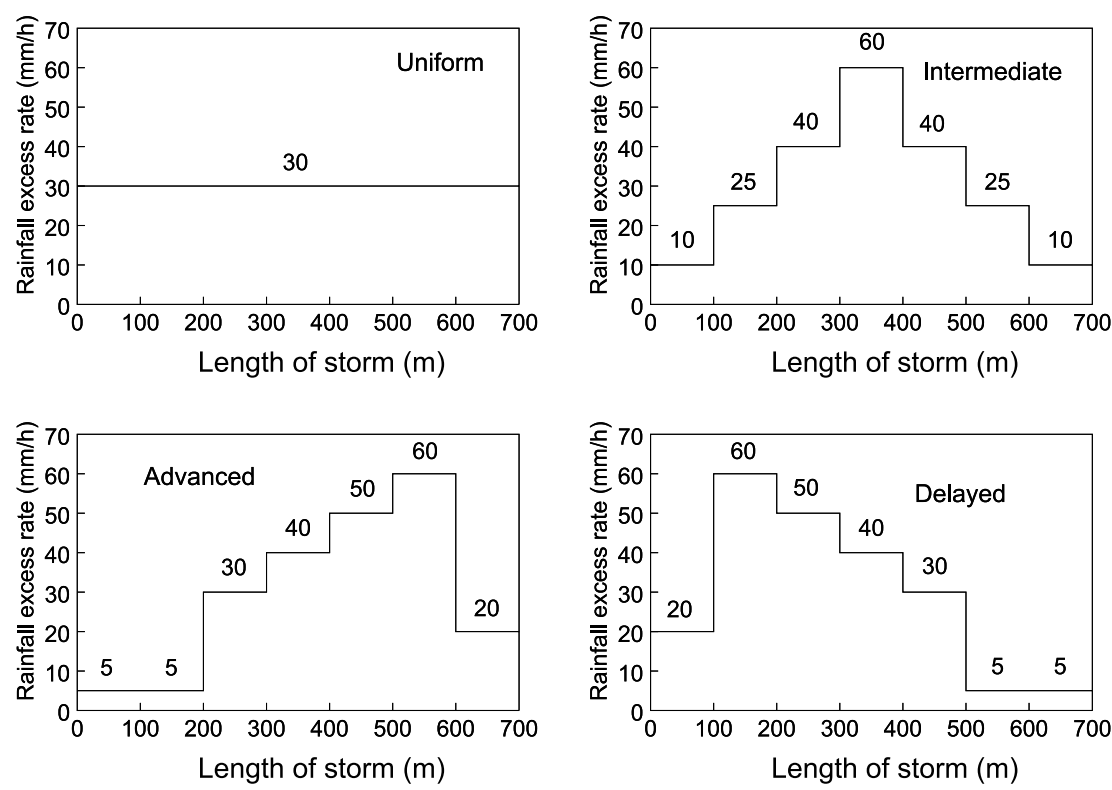

Fig. 3. Spatial rainfall intensity patterns used in this study. All the patterns produce the same amount of precipitation.

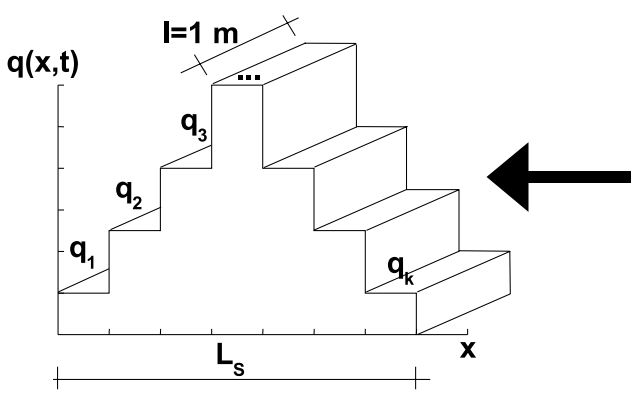

Fig. 4. Three-dimensional view of lateral inflow, per unit width, considered in the calculations (intermediate pattern - see Fig. 3).

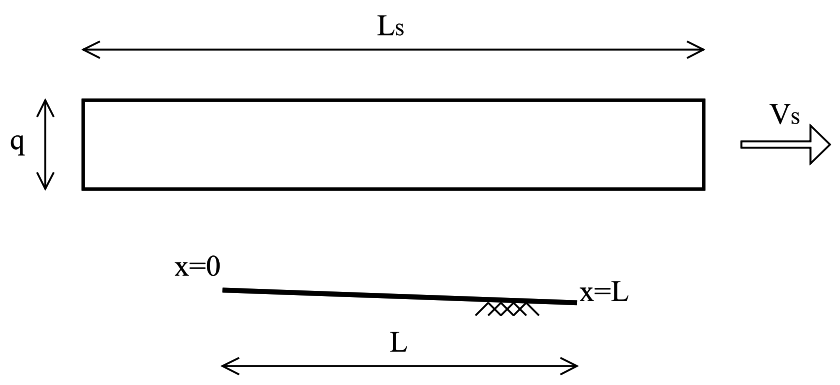

Fig. 5. Rectangular rainstorm moving across a plane (one-dimensional), at a speed of $V_{\mathrm{S}}$.

$h=\sum_{i=1}^{n} q_{i} \frac{L_{\mathrm{S}_{i}}}{V_{\mathrm{S}}}=\sum_{i=1}^{n} K_{q_{i}} \bar{q} \frac{K_{L_{i}} L}{V_{\mathrm{S}}}=\frac{\bar{q} L}{V_{\mathrm{S}}} \sum_{i=1}^{n} K_{q_{i}} K_{L_{i}}$

with

$q_{i}=K_{q_{i}} \bar{q}$

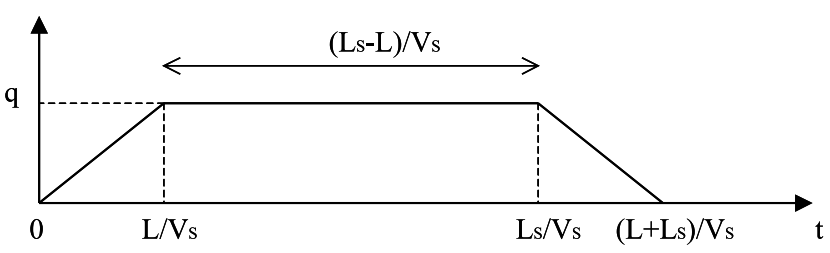

Fig. 6. Average rainfall intensity at the surface for a constant rainfall with length $L_{\mathrm{S}}$, moving across a plane as represented in Fig. 5.

$L_{\mathrm{S}_{i}}=K_{L_{i}} L$

where $\bar{q}$ is the average rainfall intensity $(\mathrm{m} / \mathrm{s}), n$ is the number of rain blocks and $K_{q_{i}}$ and $K_{L_{i}}$ are coefficients.

Since the sensitivity of runoff to storm direction decreases at high storm speeds [26], which was confirmed in this study, storm speeds of $0.5-5 \mathrm{~m} / \mathrm{s}$ were investigated. Storm movement was simulated by displacing a fixed rainfall pattern across the plane.

\section{Results}

\subsection{Comparison of storms with the same average effective rainfall rate}

For the $100 \mathrm{~m}$ long impervious plane surface, storms with different rainfall patterns were allowed to move across the plane. In order to establish the influence of spatially distributed rainfall induced by moving storms, 
simulations were performed with the four patterns presented in Fig. 3. Results are presented in Figs. 7-9, respectively for $V_{\mathrm{S}}=0.5,1$ and $2 \mathrm{~m} / \mathrm{s}$, for both downstream and upstream storm movements. Summary of main results, including rainfall pattern, storm velocity, storm direction, peak discharge and time to peak, are shown in Table 1. All patterns have the same average effective rainfall intensity of $30 \mathrm{~mm} / \mathrm{h}$ and, consequently, for the same storm speed they have the same amount of total precipitation and total runoff. Comparing hydrographs for the same storm speed, it is clear that slower storms generate larger differences in the hydrograph shapes, namely times to peak and peak discharges. The differences decrease for increasing storm speed. This is valid for both downstream and upstream storm directions.

When a storm is moving in the downstream direction (Figs. 7-9-top), which is also the direction of the flow, the beginning of runoff at the lower end of the plane is delayed and is dependent on both the storm speed and the surface flow velocity. When storm is moving in the
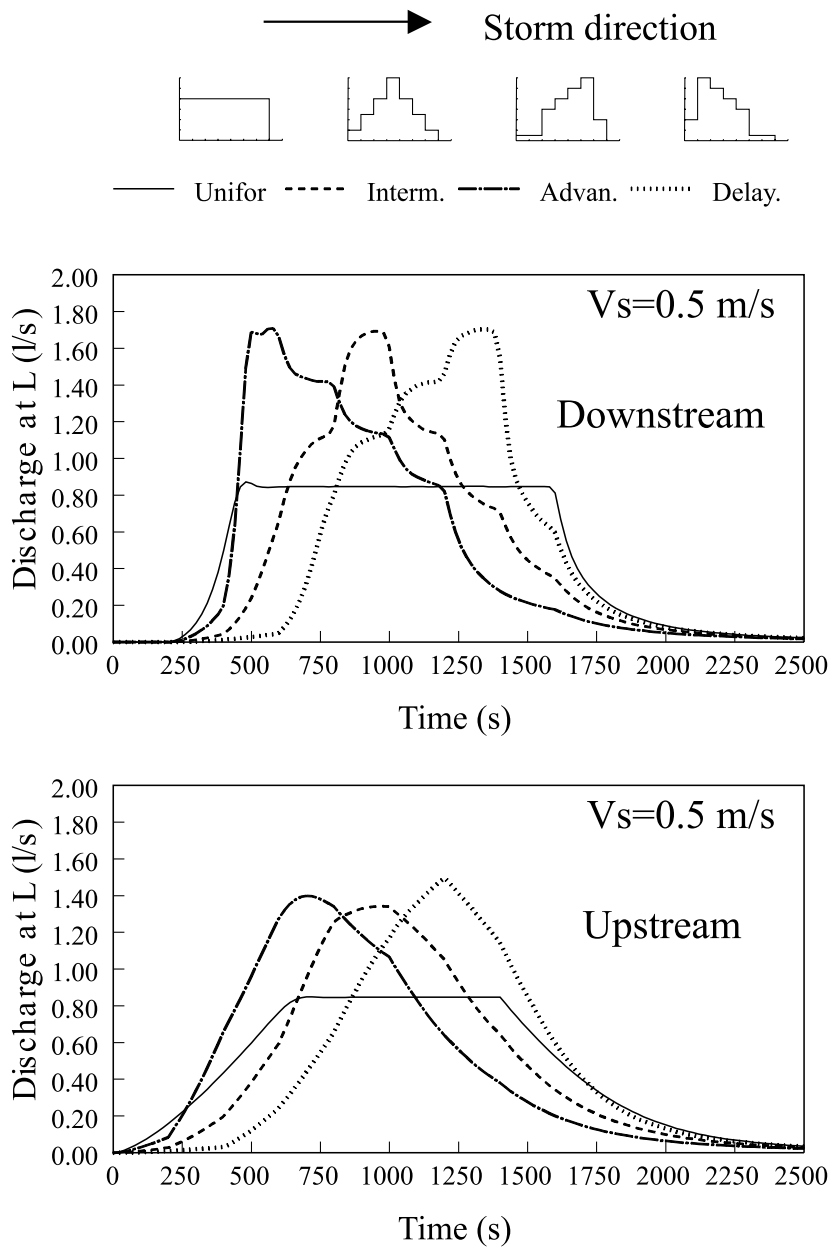

Fig. 7. Overland flow hydrographs for different storm patterns (see Fig. 3), for downstream and upstream moving rainstorms. The storm speed was $0.5 \mathrm{~m} / \mathrm{s}$.
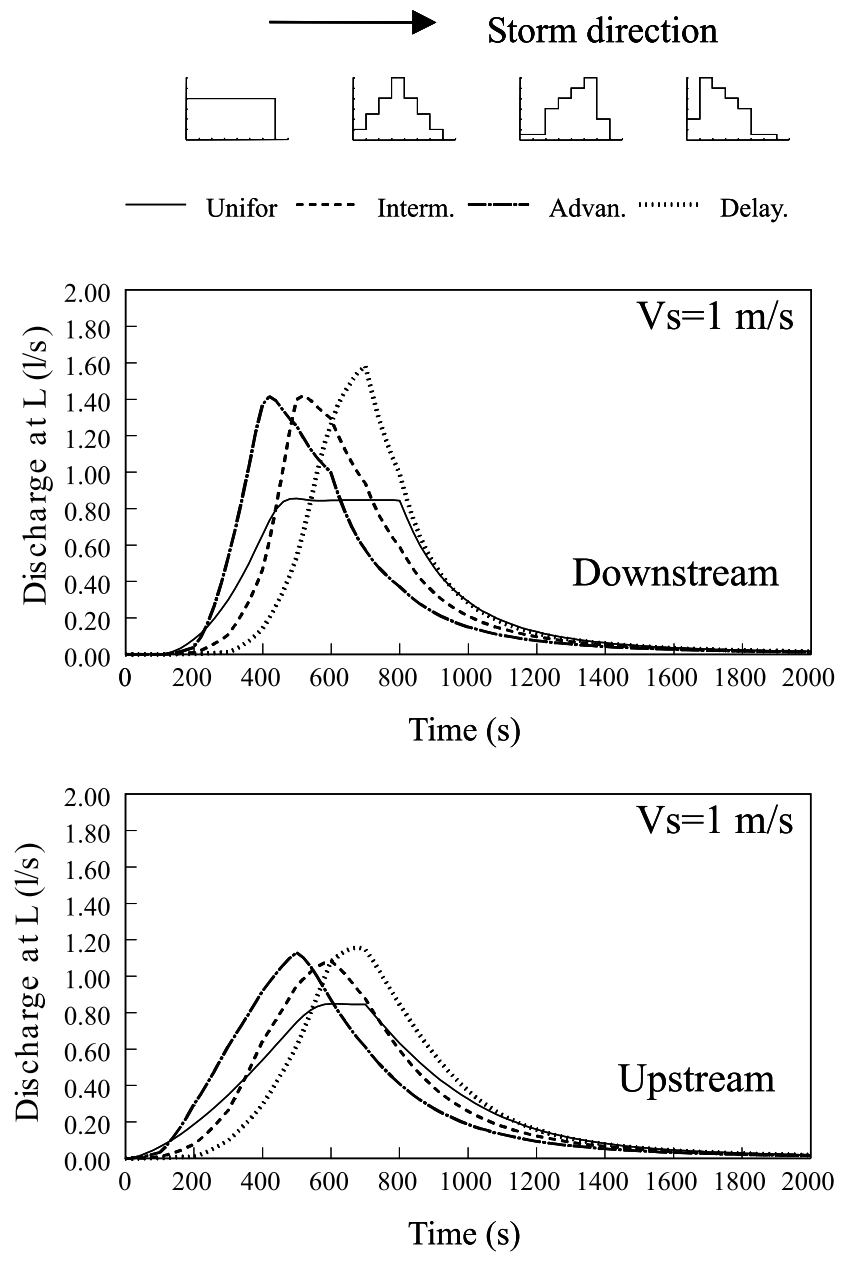

Fig. 8. Overland flow hydrographs for different storm patterns (see Fig. 3), for downstream and upstream moving rainstorms. The storm speed was $1 \mathrm{~m} / \mathrm{s}$.

upstream direction (Figs. 7-9-bottom), the time to rise is not so much dependent on the overland flow and storm speed and occurs shortly after the rainstorm enters the plane.

Since the simulated rainfall patterns, presented in Fig. 3, were invariant, irrespective of the speed of the storm, slow-moving storms produced larger amounts of rainfall and, consequently, larger amounts of runoff volume, higher peak discharges and longer base times (Figs. 7-9).

In Fig. 10, peak discharge rates, of the hydrographs presented in Figs. 7-9, are plotted against storm speed for the four rainfall patterns.

For the uniform pattern, if rain persists at a constant rate in time and space, a steady state condition will be reached for the slower moving storms, as presented in Figs. 10 and 11. If the storm is varying in its intensity over time, which is the case of the intermediate, advanced and delayed patterns, steady state will not be reached, as shown in Fig. 12, for the intermediate rainfall intensity pattern. 


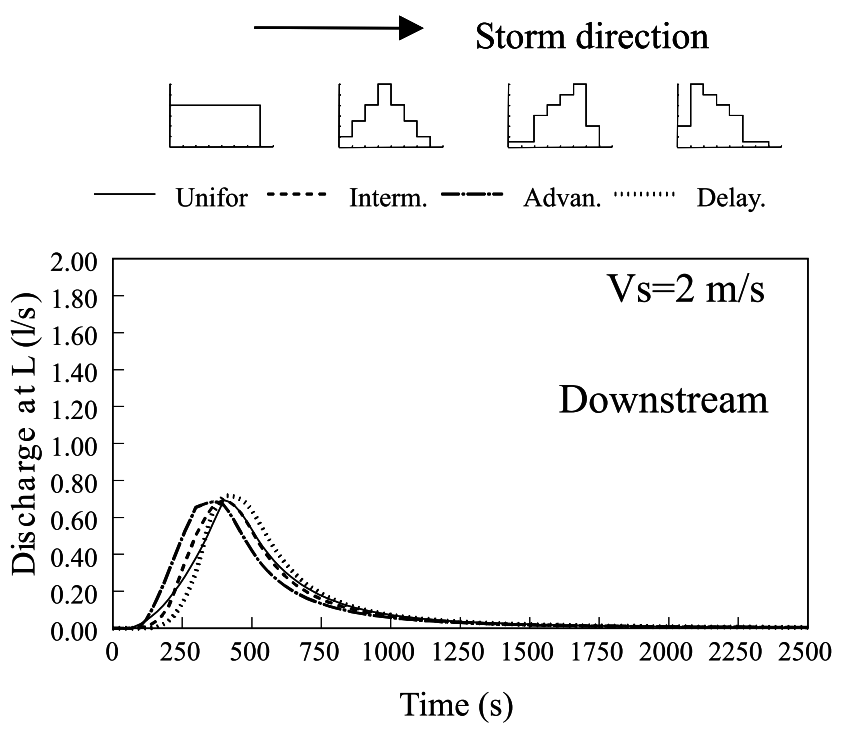

Table 1

Summary of results for three storm velocities, as presented in Figs. 7-9

\begin{tabular}{|c|c|c|c|c|c|c|}
\hline \multirow{2}{*}{$\begin{array}{l}\text { Storm } \\
\text { veloc- } \\
\text { ity } \\
(\mathrm{m} / \mathrm{s})\end{array}$} & \multirow{2}{*}{$\begin{array}{l}\text { Direc- } \\
\text { tion }\end{array}$} & \multirow{2}{*}{$\begin{array}{l}\text { Hydro- } \\
\text { graph } \\
\text { charac- } \\
\text { teristics }\end{array}$} & \multicolumn{4}{|c|}{ Rainfall patterns } \\
\hline & & & $\begin{array}{l}\text { Uni- } \\
\text { form }\end{array}$ & $\begin{array}{l}\text { Inter- } \\
\text { mediate }\end{array}$ & $\begin{array}{l}\text { Ad- } \\
\text { vanced }\end{array}$ & $\begin{array}{l}\text { De- } \\
\text { layed }\end{array}$ \\
\hline \multirow[t]{4}{*}{0.5} & $\begin{array}{l}\text { Down- } \\
\text { stream }\end{array}$ & $\begin{array}{l}Q_{L}^{\text {Peak }} \\
(1 / \mathrm{s})\end{array}$ & 0.87 & 1.69 & 1.71 & 1.70 \\
\hline & & $t_{\text {Peak }}(\mathrm{s})$ & 460 & 920 & 500 & 1320 \\
\hline & $\begin{array}{l}\text { Up- } \\
\text { stream }\end{array}$ & $\begin{array}{l}Q_{L}^{\text {Peak }} \\
(1 / \mathrm{s})\end{array}$ & $\begin{array}{l}0.85 \\
(98 \%)^{\mathrm{a}}\end{array}$ & $\begin{array}{l}1.341 \\
(79 \%)\end{array}$ & $\begin{array}{l}1.40 \\
(82 \%)\end{array}$ & $\begin{array}{l}1.50 \\
(88 \%)\end{array}$ \\
\hline & & $t_{\text {Peak }}(\mathrm{s})$ & 700 & 960 & 700 & 1200 \\
\hline \multirow[t]{4}{*}{1.0} & $\begin{array}{l}\text { Down- } \\
\text { stream }\end{array}$ & $\begin{array}{l}Q_{L}^{\text {Peak }} \\
(1 / \mathrm{s})\end{array}$ & 0.86 & 1.42 & 1.42 & 1.59 \\
\hline & & $t_{\text {Peak }}(\mathrm{s})$ & 480 & 520 & 420 & 700 \\
\hline & $\begin{array}{l}\text { Up- } \\
\text { stream }\end{array}$ & $\begin{array}{l}Q_{L}^{\text {Peak }} \\
(1 / \mathrm{s})\end{array}$ & $\begin{array}{l}0.85 \\
(99 \%)\end{array}$ & $\begin{array}{l}1.08 \\
(76 \%)\end{array}$ & $\begin{array}{l}1.13 \\
(80 \%)\end{array}$ & $\begin{array}{l}1.16 \\
(73 \%)\end{array}$ \\
\hline & & $t_{\text {Peak }}(\mathrm{s})$ & 580 & 600 & 500 & 680 \\
\hline \multirow[t]{4}{*}{2.0} & $\begin{array}{l}\text { Down- } \\
\text { stream }\end{array}$ & $\begin{array}{l}Q_{L}^{\text {Peak }} \\
(1 / \mathrm{s})\end{array}$ & 0.69 & 0.70 & 0.69 & 0.72 \\
\hline & & $t_{\text {Peak }}(\mathrm{s})$ & 400 & 400 & 360 & 400 \\
\hline & $\begin{array}{l}\text { Up- } \\
\text { stream }\end{array}$ & $\begin{array}{l}Q_{L}^{\text {Peak }} \\
(1 / \mathrm{s})\end{array}$ & $\begin{array}{l}0.50 \\
(72 \%)\end{array}$ & $\begin{array}{l}0.5 \\
(71 \%)\end{array}$ & $\begin{array}{l}0.51 \\
(74 \%)\end{array}$ & $\begin{array}{l}0.51 \\
(71 \%)\end{array}$ \\
\hline & & $t_{\text {Peak }}(\mathrm{s})$ & 360 & 360 & 340 & 360 \\
\hline
\end{tabular}

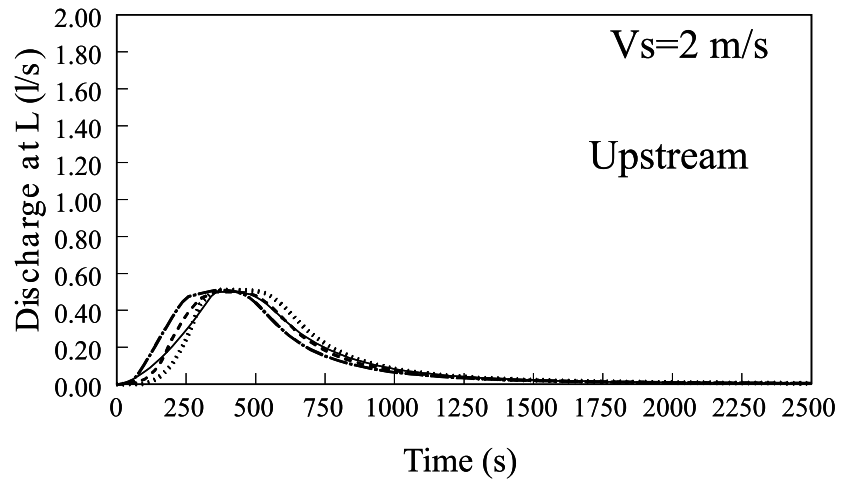

Fig. 9. Overland flow hydrographs for different storm patterns (see Fig. 3), for downstream and upstream moving rainstorms. The storm speed was $2 \mathrm{~m} / \mathrm{s}$.

\subsection{Comparison of storms with the same amount of total precipitation}

Equivalent moving storms were defined by Yen and Chow [28] as storms moving at different speeds with the same duration of rainfall at each point on the watershed and identical total rainfall volume on the catchment. To maintain constant rainfall volume between equivalent storms, Yen and Chow [28] held the precipitation intensity constant and varied the size of the storms. By this definition, equivalent storms, moving at different speeds in a certain direction, must have lengths which vary in proportion to the ratio of the storm speeds:

$L_{\mathrm{S}_{2}}=L_{\mathrm{S}_{1}} \frac{V_{\mathrm{S}_{2}}}{V_{\mathrm{S}_{1}}}$

Ogden et al. [15] used an alternative definition where the size of the storm and the total rainfall volume are equal for equivalent moving storms but have rainfall intensities which vary in proportion to the ratio of the
${ }^{\mathrm{a}}$ The percentage between brackets represents the ratio between peak discharges of upstream and downstream moving storms for a certain rainfall pattern and storm speed.

storm speeds in order to maintain constant the rainfall volume:

$q_{2}=q_{1} \frac{V_{\mathrm{S}_{2}}}{V_{\mathrm{S}_{1}}}$

In the simulations presented in this section, the total precipitation was always $h=5 \mathrm{~mm}$. However, the same spatial rainstorm patterns presented in Fig. 3 were used (with different rainfall intensities to guarantee the same total rainfall amount). The physical characteristics and catchment geometry (rectangular plane) are the same as used in the previous simulations.

\subsubsection{Equivalent moving storms of equal rainfall volume and size}

Using the definition of Yen and Chow (1969), to maintain constant rainfall volume between equivalent storms moving at different speeds, precipitation intensity was held constant and the storm size was varied. In Figs. 13 and 14 the hydrographs of equivalent storms with different rainfall patterns (total precipitation of $5 \mathrm{~mm}$ ) are compared for three storm speeds $\left(V_{\mathrm{S}}=0.5,1\right.$ and 2 $\mathrm{m} / \mathrm{s})$. Summary of main results, including rainfall pattern, storm velocity, storm direction, peak discharge, time to peak and hydrograph base time, for downstream moving storms as well as for upstream moving storms, are shown in Table 2. 

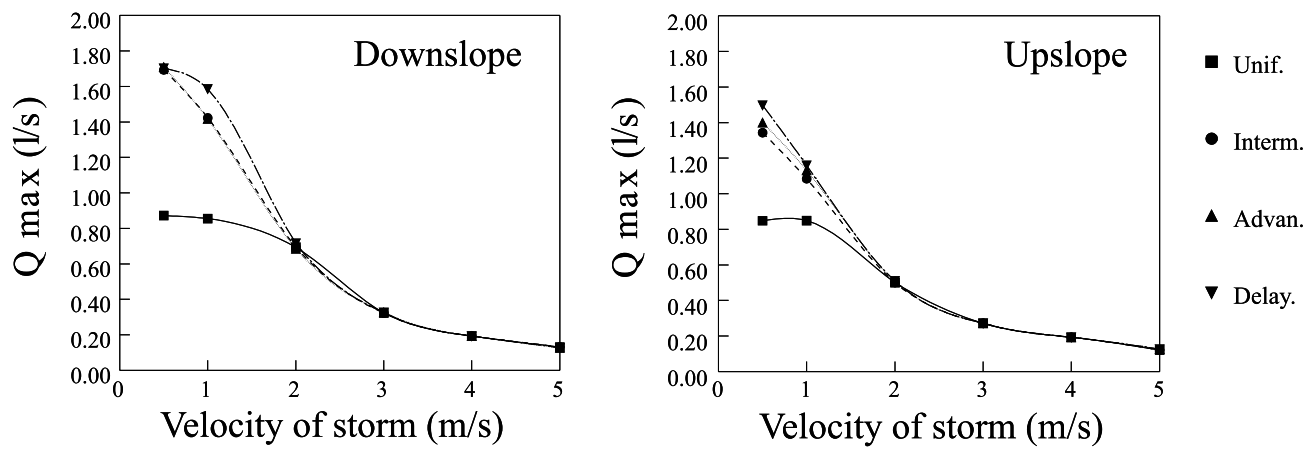

Fig. 10. Peak discharges from storms moving downstream and upstream for different storm patterns (see Fig. 3).

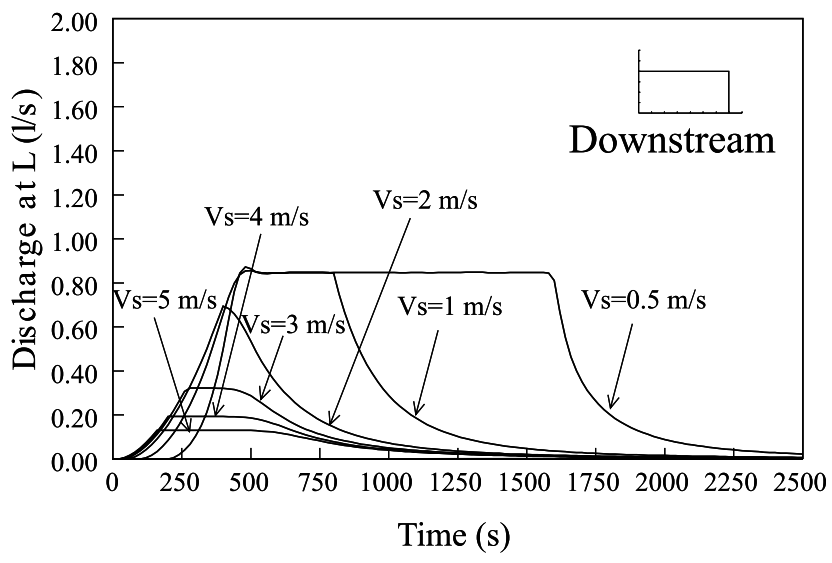

Fig. 11. Overland flow hydrographs for different storm speeds (uniform pattern, $\bar{q}=30 \mathrm{~mm} / \mathrm{h}$ ).

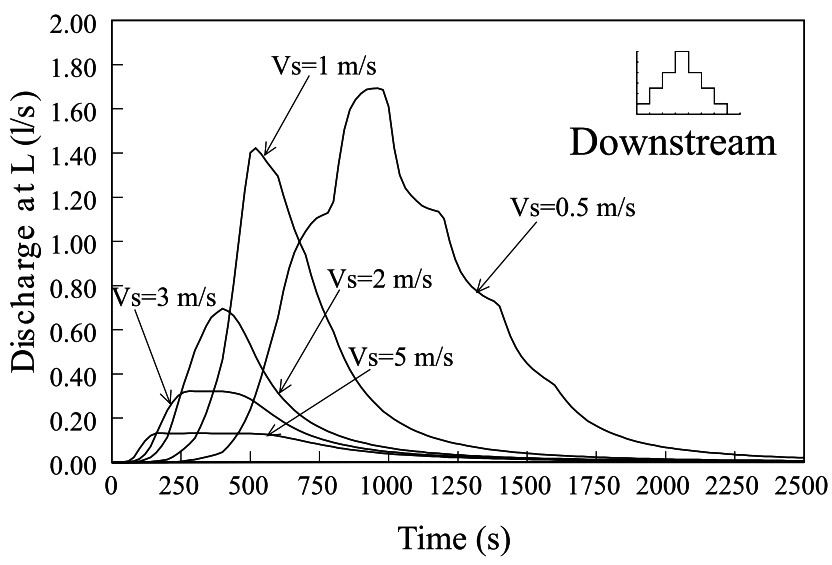

Fig. 12. Overland flow hydrographs for different storm speeds (intermediate pattern, $\bar{q}=30 \mathrm{~mm} / \mathrm{h}$ ).

A peak discharge from a storm moving downstream normally exceeds that from an equivalent storm moving upstream. Only in the case of the uniform pattern the peak discharge is equal for storms moving up and down the slope. In this case the length of the storm is sufficiently larger than the length of the plane and the steady state is reached, as illustrated in Figs. 13 and 14 (top).

For the situations studied, the downstream slowmoving storms have normally higher peak discharges, although fast-moving storms have an earlier rise (Fig. 13). The exception is the situation where the steady state is reached. The opposite situation happens for upstream moving storms (Fig. 14). It should be noted that storms of different speeds have different sizes.

The relative differences of peak discharges for equivalent storms moving in the downstream and in the upstream directions are shown in Fig. 15, for the speed of $1 \mathrm{~m} / \mathrm{s}$. A peak discharge from a storm moving downstream exceeds or equals that from a storm moving upstream.

\subsubsection{Equivalent moving storms of equal rainfall volume and precipitation intensity}

Using the definition of Ogden et al. [15], to a maintain constant rainfall volume $(h=5 \mathrm{~mm})$ between equivalent storms moving at different speeds, the size of the storm was held a constant and the precipitation intensity was varied (i.e., rainfall intensities were chosen to ensure constant total rainfall regardless of the storm speed). In Fig. 16 (downstream movement) and Fig. 17 (upstream movement) the hydrographs of equivalent storms are compared, for $V_{\mathrm{S}}=0.5,1$ and $2 \mathrm{~m} / \mathrm{s}$. Summary of main results, including rainfall pattern, storm velocity, storm direction, peak discharge, time to peak and hydrograph base time, for downstream moving storms as well as for upstream moving storms, are shown in Table 3.

The peak runoff discharge, time to peak as well as the shape of the overland flow hydrograph are significantly different for equivalent storms moving at different speeds. Whatever the rainfall intensity pattern, the faster is the moving storm then: (1) the higher is the rainfall intensity (to guarantee that the total amount of rainfall is constant; (2) the earlier and higher is the peak discharge; and (3) the shorter is the base time. This is valid for both downstream and upstream moving storms, as observed in Figs. 16 and 17. 

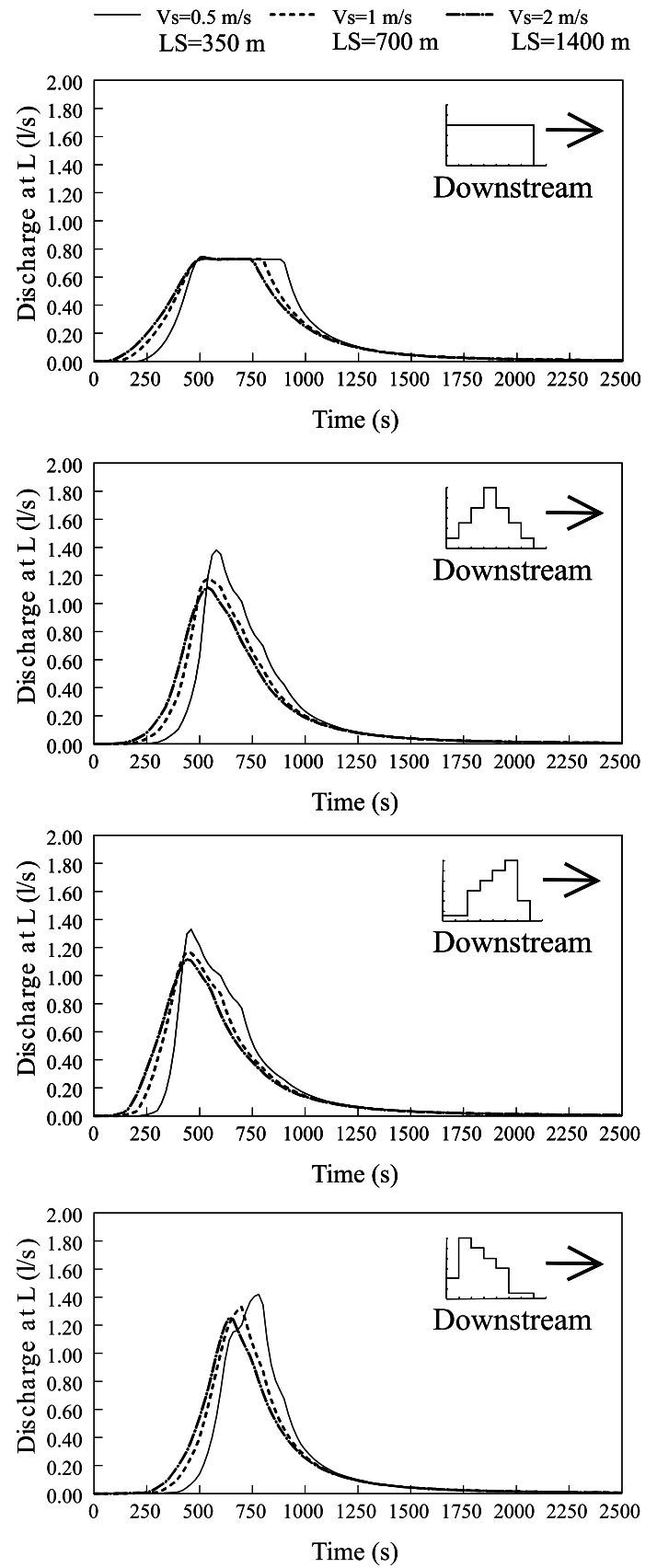

Fig. 13. Overland flow hydrographs of equivalent storms (equal rainfall volume and precipitation intensity and varying size, moving downstream at different speeds), for the uniform, intermediate, advanced and delayed patterns.

Fig. 18 (uniform pattern) and Fig. 19 (intermediate pattern) illustrate the effect of the storm direction (upstream or downstream), for equivalent storms moving at different speeds. A rainstorm moving downstream a plane produce higher peak discharges than the same storm moving upstream (or equal in the case that steady state is reached), which is strongly dependent on the storm speed.
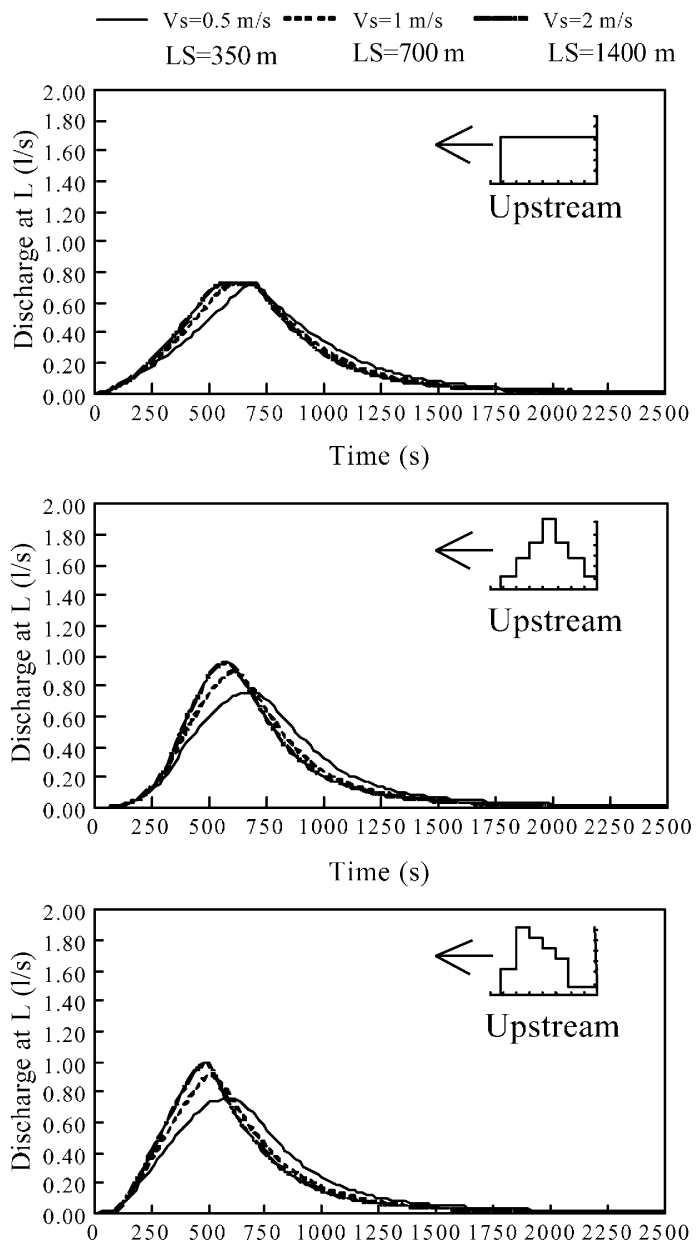

Time (s)

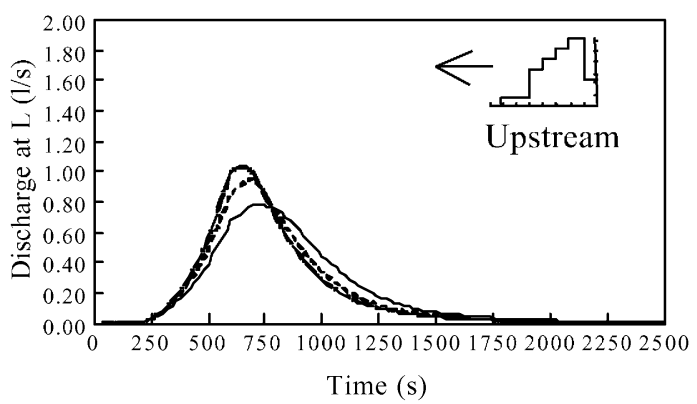

Fig. 14. Overland flow hydrographs of equivalent storms (equal rainfall volume and precipitation intensity and varying size, moving upstream at different speeds), for the uniform, intermediate, advanced and delayed patterns.

\section{Summary and conclusions}

This study deals with the description of runoff from areal and temporal distributed rainstorms, with importance for urban environments or overland flow dominated catchments, because of their rapid response, which is most sensitive to variations in rainfall. The variations in runoff are investigated numerically by moving hypo- 
Table 2

Summary of results for equivalent moving storms of equal rainfall volume and size, as presented in Figs. 13 and 14

\begin{tabular}{|c|c|c|c|c|c|c|}
\hline \multirow{2}{*}{$\begin{array}{l}\text { Direc- } \\
\text { tion }\end{array}$} & \multirow{2}{*}{$\begin{array}{l}\text { Storm } \\
\text { velocity } \\
(\mathrm{m} / \mathrm{s})\end{array}$} & \multirow{2}{*}{$\begin{array}{l}\text { Hydro- } \\
\text { graph } \\
\text { charac- } \\
\text { teristics }\end{array}$} & \multicolumn{4}{|c|}{ Pattern } \\
\hline & & & $\begin{array}{l}\text { Uni- } \\
\text { form }\end{array}$ & $\begin{array}{l}\text { Inter- } \\
\text { mediate }\end{array}$ & $\begin{array}{l}\text { Ad- } \\
\text { vanced }\end{array}$ & $\begin{array}{l}\text { De- } \\
\text { layed }\end{array}$ \\
\hline \multirow[t]{9}{*}{$\begin{array}{l}\text { Down- } \\
\text { stream }\end{array}$} & \multirow[t]{3}{*}{0.5} & $\begin{array}{l}Q_{L}^{\text {Peak }} \\
(1 / \mathrm{s})\end{array}$ & 0.74 & 1.38 & 1.33 & 1.42 \\
\hline & & $t_{\text {Peak }}(\mathrm{s})$ & 520 & 580 & 460 & 780 \\
\hline & & $t_{\text {base }}(\mathrm{s})$ & 2069 & 1960 & 1931 & 1887 \\
\hline & \multirow[t]{3}{*}{1.0} & $\begin{array}{l}Q_{L}^{\text {Peak }} \\
(1 / \mathrm{s})\end{array}$ & 0.74 & 1.18 & 1.17 & 1.33 \\
\hline & & $t_{\text {Peak }}(\mathrm{s})$ & 520 & 540 & 440 & 700 \\
\hline & & $t_{\text {base }}(\mathrm{s})$ & 2167 & 2040 & 2030 & 1980 \\
\hline & \multirow[t]{3}{*}{2.0} & $\begin{array}{l}Q_{L}^{\text {Peak }} \\
(1 / \mathrm{s})\end{array}$ & 0.73 & 1.12 & 1.12 & 1.26 \\
\hline & & $t_{\text {Peak }}(\mathrm{s})$ & 520 & 540 & 440 & 640 \\
\hline & & $t_{\text {base }}(\mathrm{s})$ & 2216 & 2092 & 2077 & 2033 \\
\hline \multirow[t]{9}{*}{$\begin{array}{l}\text { Up- } \\
\text { stream }\end{array}$} & \multirow[t]{3}{*}{0.5} & $\begin{array}{l}Q_{L}^{\text {Peak }} \\
(1 / \mathrm{s})\end{array}$ & $\begin{array}{l}0.72 \\
(97 \%)^{\mathrm{a}}\end{array}$ & $\begin{array}{l}0.76 \\
(55 \%)\end{array}$ & $\begin{array}{l}0.75 \\
(56 \%)\end{array}$ & $\begin{array}{l}0.78 \\
(55 \%)\end{array}$ \\
\hline & & $t_{\text {Peak }}(\mathrm{s})$ & 700 & 700 & 600 & 700 \\
\hline & & $t_{\text {base }}(\mathrm{s})$ & 2442 & 2334 & 2324 & 2275 \\
\hline & \multirow[t]{3}{*}{1.0} & $\begin{array}{l}Q_{L}^{\text {Peak }} \\
(1 / \mathrm{s})\end{array}$ & $\begin{array}{l}0.73 \\
(99 \%)\end{array}$ & $\begin{array}{l}0.90 \\
(76 \%)\end{array}$ & $\begin{array}{l}0.92 \\
(79 \%)\end{array}$ & $\begin{array}{l}0.96 \\
(72 \%)\end{array}$ \\
\hline & & $t_{\text {Peak }}(\mathrm{s})$ & 620 & 600 & 500 & 700 \\
\hline & & $t_{\text {base }}(\mathrm{s})$ & 2343 & 2235 & 2224 & 2176 \\
\hline & \multirow[t]{3}{*}{2.0} & $\begin{array}{l}Q_{L}^{\text {Peak }} \\
(1 / \mathrm{s})\end{array}$ & $\begin{array}{l}0.73 \\
(99 \%)\end{array}$ & $\begin{array}{l}0.96 \\
(86 \%)\end{array}$ & $\begin{array}{l}1.00 \\
(89 \%)\end{array}$ & $\begin{array}{l}1.04 \\
(83 \%)\end{array}$ \\
\hline & & $t_{\text {Peak }}(\mathrm{s})$ & 580 & 580 & 500 & 640 \\
\hline & & $t_{\text {base }}(\mathrm{s})$ & 2305 & 2197 & 2187 & 2118 \\
\hline
\end{tabular}

${ }^{\mathrm{a}}$ The percentage between brackets represents the ratio between peak discharges of upstream and downstream moving storms for a certain rainfall pattern and storm speed.

thetical storms, up and down an idealized catchment (impervious plane surface) at a range of speeds. To evaluate the hydrologic response of storm movement, four arbitrary selected fixed lateral inflow patterns (uniform, intermediate, advanced and delayed), with a certain spatial extent, were considered moving in space. The numerical simulations, using the kinematic wave equation, did not account for time varying losses such as abstraction and infiltration.

The main finding of this study is that peak discharges and hydrograph shapes depend strongly on the storm pattern. However, these differences also depend strongly on catchment characteristics and on the direction and speed of storms. The main conclusions are:

- As also concluded elsewhere (e.g., [6,12,22]), two distinct hydrologic responses are observed for storms moving upstream and downstream. Storms moving upstream are normally characterised by hydrographs with: (1) early rise, (2) low peak discharge, (3) not so steep rising limb, and (4) long base time.
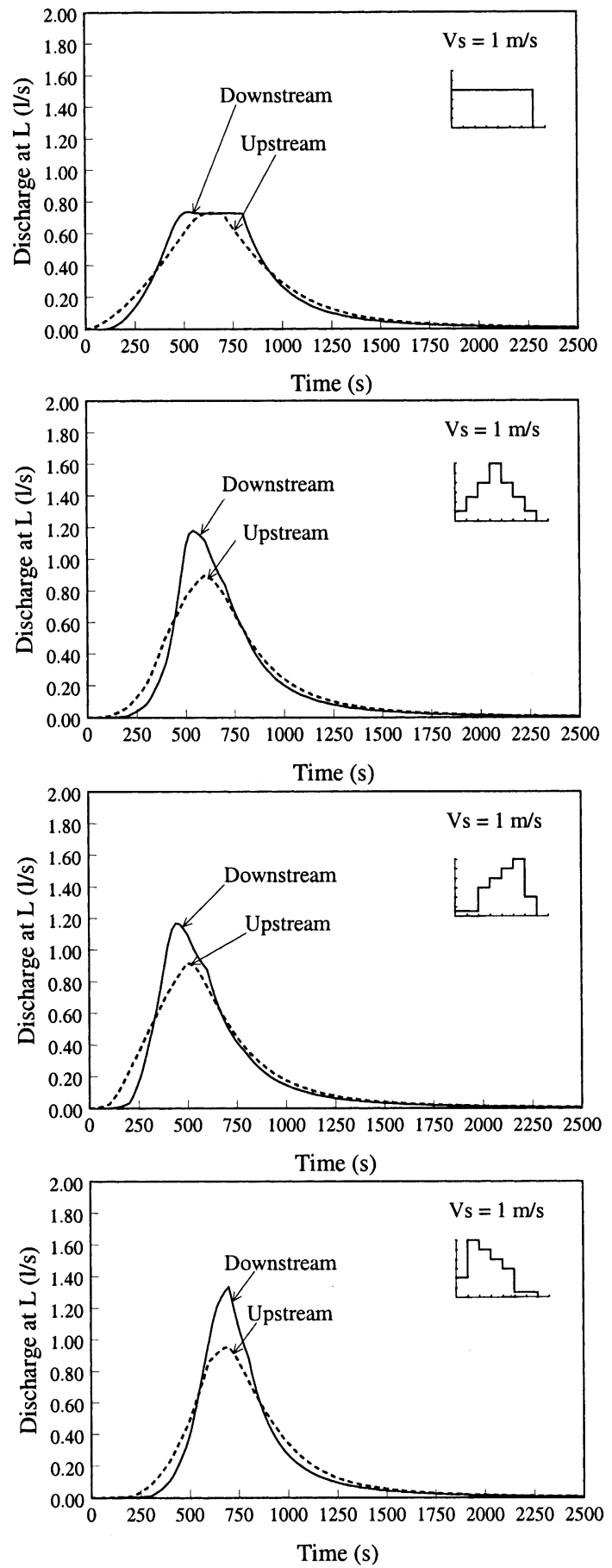

Fig. 15. Effect of storm-movement direction (upstream and downstream) on hydrographs for equivalent storms (equal rainfall volume and precipitation intensity), for storm moving at a speed of $1 \mathrm{~m} / \mathrm{s}$, for the uniform, intermediate, advanced and delayed storm patterns.

- The sensitivity of runoff to storm patterns decreases at high storm speeds. Rainfall intensity patterns are important in the hydrological response (e.g., prediction of peak runoff discharge, time to peak as well as the shape of the overland flow hydrograph) for slow moving storms. 

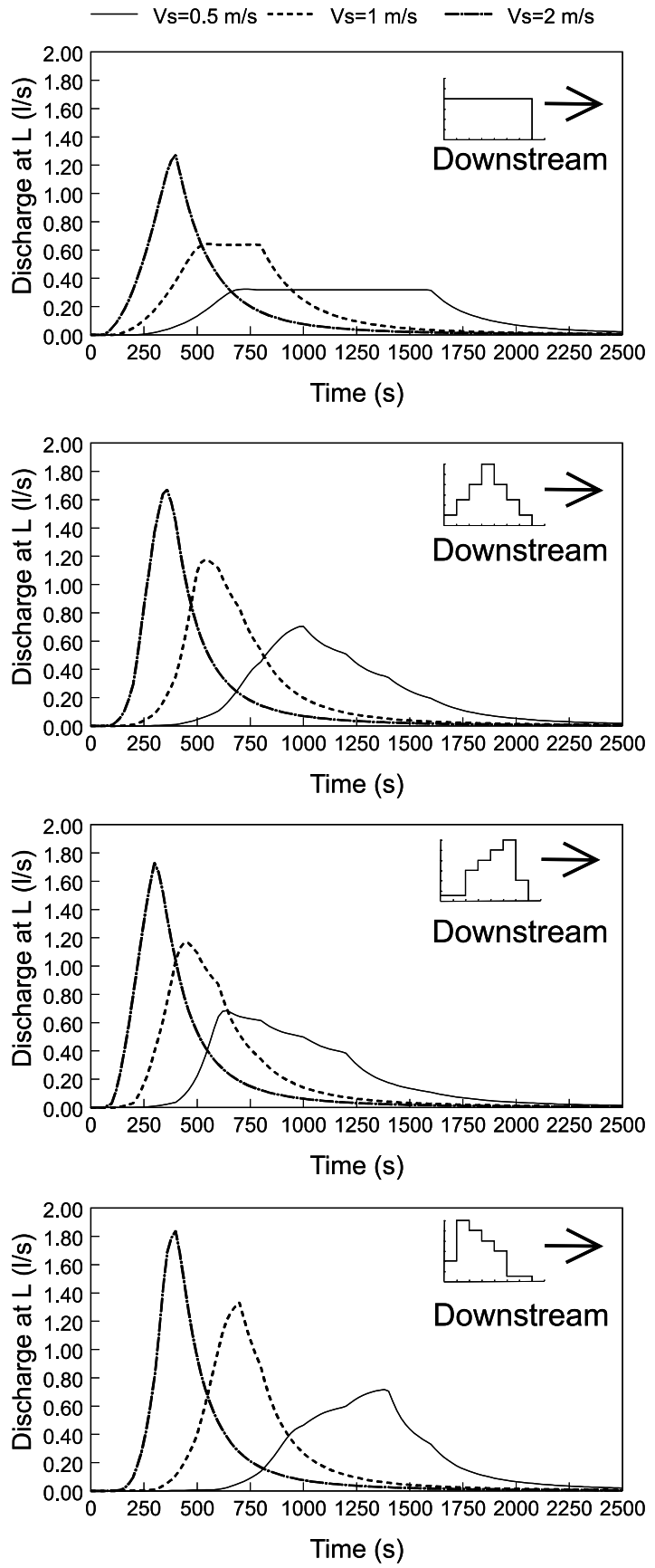

Fig. 16. Overland flow hydrographs of equivalent storms (equal rainfall volume and size and varying precipitation intensity, moving downstream at different speeds), for the uniform, intermediate, advanced and delayed patterns.

- When comparing equivalent storms, downstream storm movement presents bigger differences in the hydrograph shapes for different rainfall patterns than do the upstream movement.

- Hydrographs, times to peak and peak discharges of equivalent storms determined according to the definition of Ogden et al. [15] present significantly larger
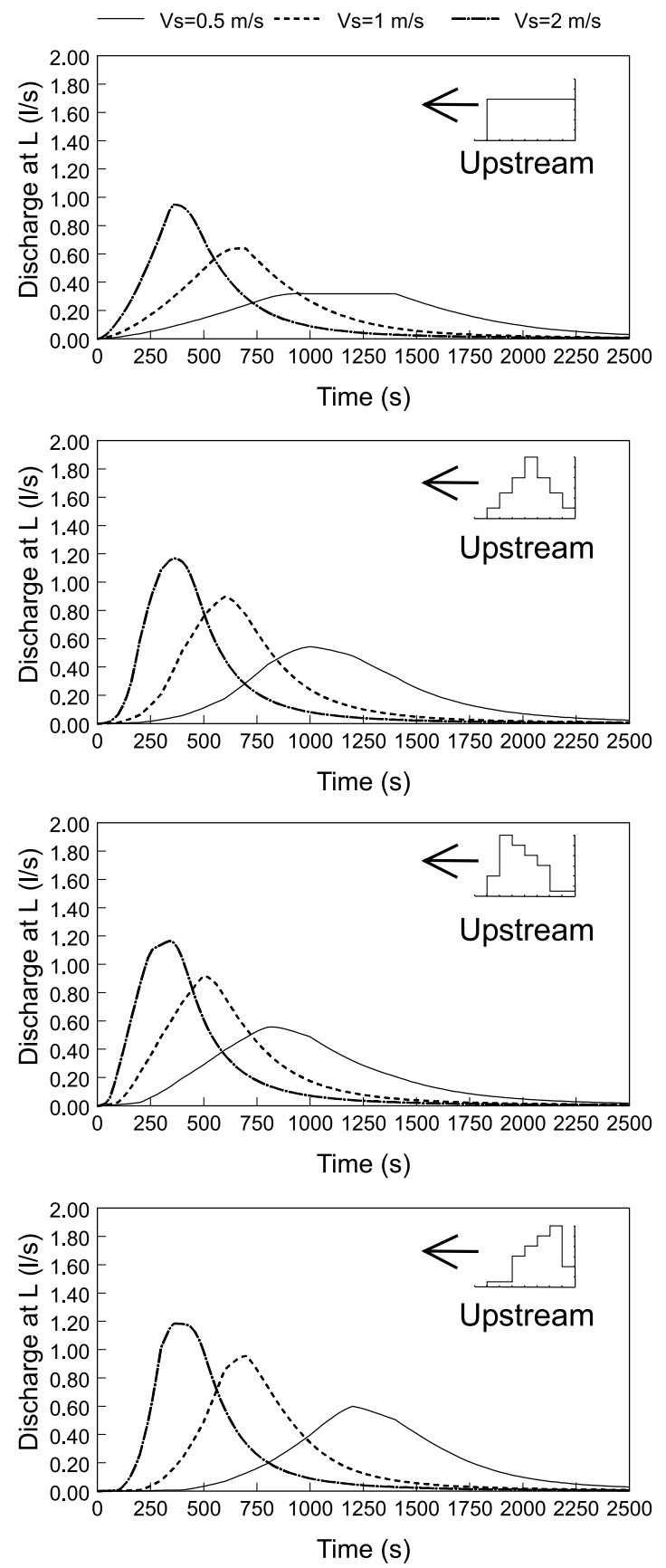

Fig. 17. Overland flow hydrographs of equivalent storms (equal rainfall volume and size and varying precipitation intensity, moving upstream at different speeds), for the uniform, intermediate, advanced and delayed patterns.

differences than those determined according to the definition of Yen and Chow (1969).

The numerical results should not be extrapolated to other situations without caution, due mainly to the assumption of the rainfall pattern (e.g., fixed pattern, independent of storm speed and direction), a very sim- 
Table 3

Summary of results for equivalent moving storms of equal rainfall volume and precipitation intensity, as presented in Figs. 16 and 17

\begin{tabular}{|c|c|c|c|c|c|c|}
\hline \multirow{2}{*}{$\begin{array}{l}\text { Direc- } \\
\text { tion }\end{array}$} & \multirow{2}{*}{$\begin{array}{l}\text { Storm } \\
\text { velocity } \\
(\mathrm{m} / \mathrm{s})\end{array}$} & \multirow{2}{*}{$\begin{array}{l}\text { Hydro- } \\
\text { graph } \\
\text { charac- } \\
\text { teristics }\end{array}$} & \multicolumn{4}{|l|}{ Pattern } \\
\hline & & & $\begin{array}{l}\text { Uni- } \\
\text { form }\end{array}$ & $\begin{array}{l}\text { Inter- } \\
\text { mediate }\end{array}$ & $\begin{array}{l}\text { Ad- } \\
\text { vanced }\end{array}$ & $\begin{array}{l}\text { De- } \\
\text { layed }\end{array}$ \\
\hline \multirow[t]{9}{*}{$\begin{array}{l}\text { Down- } \\
\text { stream }\end{array}$} & \multirow[t]{3}{*}{0.5} & $\begin{array}{l}Q_{L}^{\text {Peak }} \\
(1 / \mathrm{s})\end{array}$ & 0.32 & 0.70 & 0.69 & 0.71 \\
\hline & & $t_{\text {Peak }}(\mathrm{s})$ & 700 & 980 & 640 & 1360 \\
\hline & & $t_{\text {base }}(\mathrm{s})$ & 2685 & 2500 & 2500 & 2350 \\
\hline & \multirow[t]{3}{*}{1.0} & $\begin{array}{l}Q_{L}^{\text {Peak }} \\
(1 / \mathrm{s})\end{array}$ & 0.64 & 1.18 & 1.17 & 1.33 \\
\hline & & $t_{\text {Peak }}(\mathrm{s})$ & 520 & 540 & 440 & 700 \\
\hline & & $t_{\text {base }}(\mathrm{s})$ & 2140 & 2040 & 2030 & 1980 \\
\hline & \multirow[t]{3}{*}{2.0} & $\begin{array}{l}Q_{L}^{\text {Peak }} \\
(1 / \mathrm{s})\end{array}$ & 1.27 & 1.67 & 1.73 & 1.84 \\
\hline & & $t_{\text {Peak }}(\mathrm{s})$ & 400 & 360 & 300 & 400 \\
\hline & & $t_{\text {base }}(\mathrm{s})$ & 1892 & 1840 & 1825 & 1817 \\
\hline \multirow[t]{9}{*}{$\begin{array}{l}\text { Up- } \\
\text { stream }\end{array}$} & \multirow[t]{3}{*}{0.5} & $\begin{array}{l}Q_{L}^{\text {Peak }} \\
(1 / \mathrm{s})\end{array}$ & $\begin{array}{l}0.32 \\
(100 \%)^{\mathrm{a}}\end{array}$ & $\begin{array}{l}0.54 \\
(77 \%)\end{array}$ & $\begin{array}{l}0.56 \\
(81 \%)\end{array}$ & $\begin{array}{l}0.60 \\
(85 \%)\end{array}$ \\
\hline & & $t_{\text {Peak }}(\mathrm{s})$ & 920 & 1000 & 820 & 1200 \\
\hline & & $t_{\text {base }}(\mathrm{s})$ & 3053 & 2847 & 2827 & 2710 \\
\hline & \multirow[t]{3}{*}{1.0} & $\begin{array}{l}Q_{L}^{\text {Peak }} \\
(1 / \mathrm{s})\end{array}$ & $\begin{array}{l}0.64 \\
(100 \%)\end{array}$ & $\begin{array}{l}0.90 \\
(76 \%)\end{array}$ & $\begin{array}{l}0.92 \\
(79 \%)\end{array}$ & $\begin{array}{l}0.96 \\
(72 \%)\end{array}$ \\
\hline & & $t_{\text {Peak }}(\mathrm{s})$ & 660 & 600 & 500 & 700 \\
\hline & & $t_{\text {base }}(\mathrm{s})$ & 2333 & 2235 & 2224 & 2176 \\
\hline & \multirow[t]{3}{*}{2.0} & $\begin{array}{l}Q_{L}^{\text {Peak }} \\
(1 / \mathrm{s})\end{array}$ & $\begin{array}{l}0.95 \\
(75 \%)\end{array}$ & $\begin{array}{l}1.17 \\
(70 \%)\end{array}$ & $\begin{array}{l}1.17 \\
(68 \%)\end{array}$ & $\begin{array}{l}1.18 \\
(64 \%)\end{array}$ \\
\hline & & $t_{\text {Peak }}(\mathrm{s})$ & 360 & 360 & 340 & 360 \\
\hline & & $t_{\text {base }}(\mathrm{s})$ & 1980 & 1933 & 1934 & 1900 \\
\hline
\end{tabular}

${ }^{\mathrm{a}}$ The percentage between brackets represents the ratio between peak discharges of upstream and downstream moving storms for a certain rainfall pattern and storm speed.

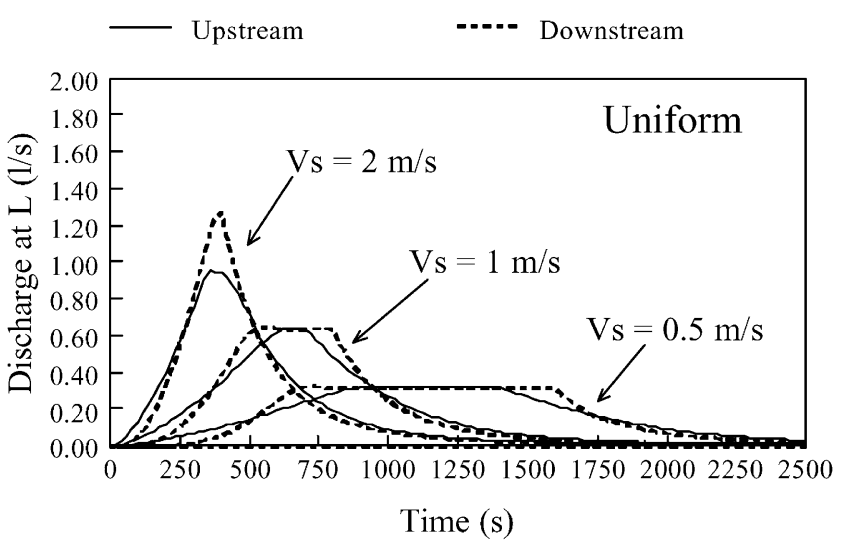

Fig. 18. Effect of direction of storm movement (upstream and downstream) on hydrographs for equivalent storms (equal rainfall volume and storm size), for storm moving at various speeds, for the uniform storm pattern.

ple catchment (e.g., plane surface) and of the numerical scheme (e.g., one-dimensional kinematic wave model).

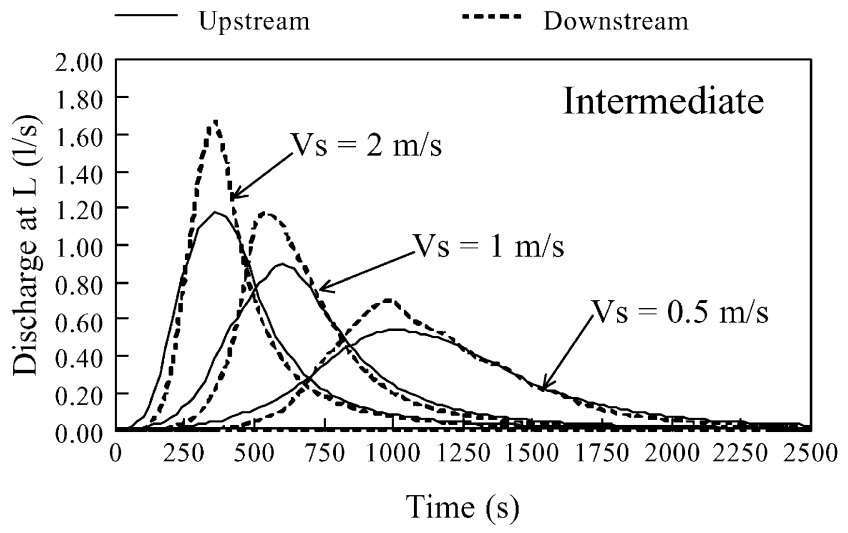

Fig. 19. Effect of direction of storm movement (upstream and downstream) on hydrographs for equivalent storms (equal rainfall volume and storm size), for storm moving at various speeds, for the intermediate storm pattern.

\section{Acknowledgement}

This study was partly supported by the Portuguese Foundation for Science and Technology (Project FCT/ MCT_SAPIENS POCTI/1999/MGS/35661).

\section{References}

[1] Campbell SY, van der Molen WH, Rose CW, Parlange JY. A new method for obtaining a spatially averaged infiltration rate from rainfall and runoff rates. J Hydrol 1985;82:57-68.

[2] Constantinides CA. Numerical techniques for a two-dimensional kinematic overland flow model. Water SA 1981;7(4):234-48.

[4] Horton RE. Erosional development of streams and their drainage basins: hydro-physical approach to quantitative morphology. Geol Soc Am Bull 1945;56:275-370.

[5] Henderson FM, Wooding RA. Overland flow and groundwater flow from a steady rainfall of finite duration. J Geophys Res 1964;69:1513-40.

[6] Jensen M. Runoff pattern and peak flows from moving block rains based on linear time-area curve. Nord Hydrol 1984;15:155-68.

[7] de Lima JLMP. Overland flow under rainfall. PhD Thesis, Wageningen Agricultural University, The Netherlands. 1989.

[8] de Lima JLMP. The influence of the angle of incidence of the rainfall on the overland flow process. In: Kavvas ML, editor. New directions for surface water modeling, vol 181. IAHS Publ; 1989. p. 73-82.

[9] de Lima JLMP, Torfs PJJF. Effects of wind on simulated rainfall and overland flow under single full-cone nozzle sprays. In: Trakiris G, Santos MA, editors. Proceedings of the Second European Conference on Advances in Water Resources Technology and Management, Lisbon, Portugal. Rotterdam: Balkema; 1994. p. 443-50.

[10] de Lima JLMP, Nunes MAC. Modelação numérica de simuladores de chuva. Cadernos de Geografia, Instituto de Estudos Geográficos, FLUC 1995;14:115-28 (in Portuguese).

[11] de Lima JLMP, van der Molen WH. An analytical kinematic model for the rising limb of overland flow on infiltrating parabolic shaped surfaces. J Hydrol 1988;104:363-70.

[12] de Lima JLMP, Singh VP. The influence of storm movement on overland flow-Laboratory experiments under simulated rainfall. 
In: Singh VP, Seo II W, Sonu JH, editors. Hydrologic Modeling Proceedings of the International Conference on Water, Environmental, Ecology, Socio-economics and Health Engineering (WEESHE), Seoul National University, Seoul, Korea. Fort Collins, Colorado: Water Resources Publications; 1999. p. 101-11.

[13] Maksimov VA. Computing runoff produced by a heavy rainstorm with a moving center. Sov Hydrol 1964;5:510-3.

[14] Nakajima C. Heavy rainfall and disasters. Bull Disas Prev Res Inst, Kyoto Univ 1973;22(4):231-48.

[15] Ogden FL, Richardson JR, Julien PY. Similarity in catchment response. 2. Moving storms. Water Resour Res 1995;31(6): 1543-7.

[16] Parlange JY, Rose CW, Sander G. Kinematic flow approximation of runoff on a plane: An exact analytical solution. J Hydrol 1981;52:171-6.

[17] Robertson AF, Turner AK, Crow FR, Ree WO. Runoff from impervious surfaces under conditions of simulated rainfall. Trans ASAE 1966;9(3):343-51.

[18] Savat J. The hydraulics of sheet flow on a smooth surface and the effect of simulated rainfall. Earth Surf Process 1977;2:125-40.

[19] Shen HW, Li RW. Rainfall effect on sheet flow over smooth surfaces. J Hydrol Div, ASCE 1973;99(5):771-92.
[20] Singh VP. Kinematic wave modelling in water resources: surfacewater hydrology. Chichester: John Wiley and Sons Ltd; 1996.

[21] Singh VP. Kinematic wave modelling in water resources: environmental hydrology. Chichester: John Wiley and Sons Ltd; 1997.

[22] Singh VP. Effect of the direction of storm movement on planar flow. Hydrol Process 1998;12:147-70.

[23] Stephenson D, Meadows ME. Kinematic hydrology and modelling. In: Developments in water science, vol 26. Amsterdam: Elsevier Science Publishers; 1986.

[24] Yen BC, Chow VT. A study of surface runoff due to moving rainstorms. Hydraulic Engineering Series No. 17, Department of Civil Engineering, University of Illinois, Urbana. 1968.

[25] Yoon YN, Wenzel HG. Mechanics of sheet flow under simulated rainfall. J Hydrol Div, ASCE 1971;97:1367-86.

[26] Watts LG, Calver A. Effects of spatially-distributed rainfall on runoff for a conceptual catchment. Nord Hydrol 1991;22:1-14.

[27] Woolhiser DA. Simulation of unsteady overland flow. In: Mahmood K, Yevjevich V, editors. Unsteady flow in open channels, vol II. Fort Collins, Colorado: Water Resources Publications; 1975. p. 485-508.

[28] Yen BC, Chow VT. A laboratory study of surface runoff due to moving rainstorms. Water Resour Res 1969;5(5):989-1006. 